ELORE (ISSN 1456-3010), vol. $16-2 / 2009$.

Julkaisija: Suomen Kansantietouden Tutkijain Seura ry.

[http://www.elore.fi/arkisto/2_09/kirjallisuus_hammarstrom_2_09.pdf]

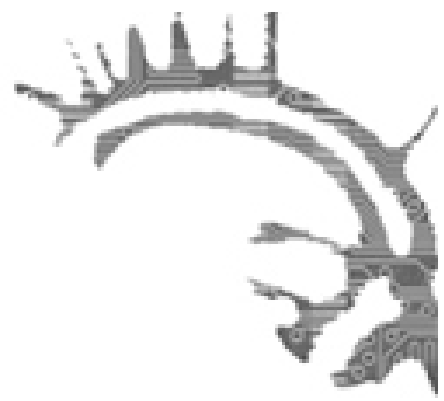

\title{
KiRJA-ARVIO:
}

\section{SUKELLUS SAARISTOKULTTUUREIHIN}

Siivonen, Katriina 2008: Saaristoidentiteetit merkkien virtoina. Varsinaissuomalainen arki ja aluekehitystyö globalisaation murroksessa. Helsinki: Kansatieteellinen arkisto 51. 408 sivua.

\section{$\underline{\text { Kukka Hammarström }}$}

Katriina Siivonen on tarkastellut kansatieteen alaan kuuluvassa väitöskirjassaan Saaristoidentiteetit merkekien virtoina varsinaissuomalaisten saaristoidentiteettien rakentumista ihmisten arjessa ja aluekehitystyössä sekä suhteessa laajempiin, globaaleihin prosesseihin ja informaatioajan murrokseen. Ajallisesti tutkimus sijoittuu 1990-2000-lukujen taitteeseen, jolloin Euroopan Unioniin liittymisen myötä sen kulttuuripolitiikkaa ja aluekehitystyön hankkeita ryhdyttiin toteuttamaan myös Suomessa.

Siivonen kiinnittyy metodologisesti etnologiseen sekä laajempaan antropologiseen tutkimustraditioon kenttätyön ja kulttuurin käsitteen määrittelyn kautta. Hän nimeää tutkimuksensa yhdeksi tavoitteeksi uudenlaisen kulttuuria koskevan teoreettisen lähestymistavan luomisen sekä sen soveltamisen käytäntöön esimerkkinä olevan tapaustutkimuksen kautta. Tutkimus ottaa osaa paitsi tieteenteoreettiseen keskusteluun myös ajankohtaiseen haasteeseen kulttuurisesti kestävän kehityksen toteutumismahdollisuuksista.

\section{NÄKYMÄ SAARISTOON}

Siivonen lähestyy tutkimuskohdettaan pohtimalla, mikä on saaristossa asuvien ihmisten suhde kotipaikkaansa sekä millaisia merkityksiä esimerkiksi etnisyys, alueellisuus ja identiteetti saavat suhteessa siellä asuvien arkeen sekä toisaalta aluekehitystyöhön. Hän nostaa esiin myös alueellisen kulttuurin ja identiteettien suhteen kansalliselta ja 


\section{KUKKA HAMMARSTRÖM}

Euroopan Unionin taholta ohjattuihin projekteihin sekä laajemmat globaalit prosessit ja niiden murrokset.

Tutkimus jakautuu seitsemään osioon. Ensimmäisessä osassa Siivonen määrittelee tutkimuskohteensa ja teoreettiset valintansa. Toinen osa esittelee yleisesti saaristoon kohdistunutta tutkimusta ja keskittyy erityisesti käsittelemään hänen käyttämäänsä semioottisen kulttuurin teoriaa, jonka kautta hän jäsentää myös identiteetin käsitettä. Kolmannessa osassa tarkastelun kohteena ovat muun muassa globaalin kulttuurin ja informaatioajan murros, suomenruotsalaisuus sekä Euroopan Unionin alue- ja kulttuuripolitiikka ja siihen integroitu aluekehitystyö. Neljäs osa puolestaan esittelee tutkimuksen metodologiaa, aineistoa ja tutkimusprosessia itsessään. Varsinaiseen aineiston analyysiin paneudutaan osissa viisi ja kuusi. Niissä käydään tarkemmin läpi saariston rajautumista ja saaristoidentiteettien sisältöjä sekä suhteessa saariston asukkaiden arkeen että aluekehitystyöhön. Seitsemäs ja viimeinen osa pohtivat käytetyn teorian hyötyä ja mahdollisuuksia sekä tiivistävät siihen perustuvan analyysin tulokset.

Siivosen tutkimuskenttä kattaa alueellisesti Varsinais-Suomen saariston ja sen saaristolaissa määritellyt osat. Tutkimuksen aineisto koostuu pääosin saariston asukkaiden ja siellä aluekehitystyön hankkeissa toimivien haastatteluista. Mukana on havainnointiaineistoa saariston kehittämistyötä tekevien organisaatioiden seminaareista. Siivonen itse on toiminut erilaisissa saariston kehittämishankkeissa, jollaiseksi hän myös tutkimuksensa määrittää.

\section{KULTTUURI MERKKEINÄ JA PROSESSINA}

Siivonen soveltaa kulttuurin tarkasteluun Charles S. Piercen kehittämää semioottista mallia. Hän sijoittaa analyysinsa samalla osaksi laajempaa kulttuuriteoreettista keskustelua, josta työvälineiksi nousevat erityisesti Ulf Hannerzin ja Fredrik Barthin tutkimukset. Asiaan vihkiytymättömälle Piercen semiotiikka ja sen merkkeihin perustuva käsitemaailma on ensi lukemalta haastava. Siivonen suhteuttaa omaa teoriaansa kuitenkin tarkasti ja selkeästi muuhun, erityisesti antropologiseen kulttuurin käsitettä koskevaan tutkimukseen, mikä johdattaa lukijaa ymmärtämään antroposemiosiksen prosessiksi kutsuttua lähestymistapaa kulttuurin tarkasteluun. Antroposemiosis kytkeytyy nykypäivän yleisempään teoreettiseen kulttuuria koskevaan näkemykseen, jossa kulttuuri nähdään häilyvärajaisena, alati muuntuvana, vuorovaikutteisena ja monimuotoisena prosessina.

Siivosen lähtökohtana on ajatus yksilöstä kulttuurin perustana ja samalla osana laajempaa, koko ihmiskunnan kattavaa, ajallisesti ja paikallisesti varioivaa verkostoa. Ihminen havainnoi ympäristöään ja nämä havainnot jäsentyvät tiedoksi merkkien avulla. Merkit liittyvät toisiinsa vuorovaikutusprosessissa muodostaen ketjuja ja lopulta globaalin merkkien verkoston, antroposemiosiksen prosessin. Kulttuuri on yksi osa tätä prosessia. Antroposemiosis viittaa ihmisen ja hänen ympäristönsä vuorovaikutteiseen suhteeseen, semiosis kattaa puolestaan laajemman luonnon kokonaisuuden. Siivonen yhdistää myös itse tutkimusprosessin osaksi antroposemiosiksen verkostoa ja toteaa: "Tutkimus on osa kulttuuria ja kulttuuri tutkimuksen kohde" (s. 126). Tämä 
liittyy nähdäkseni paitsi tutkimustyötä reflektoiviin kysymyksiin myös tapaan nähdä ja määritellä kulttuuri itsessään vuorovaikutteisiksi verkostoiksi.

\section{MONINAISET SAARISTOIDENTITEETIT}

Siivosen luotsaamalla matkalla saaristoon sen luonto ja meri näyttäytyvät erottamattomana osana ihmisten elinympäristöä. Saariston asukkaat kiinnittyvät arkisessa elämässä monin tavoin kotipaikkaansa, esimerkiksi sukujuurten ja elinkeinojen kautta. Saaristo ja saaristolaisuus itsessään sisältävät erilaisia rajauksia ja merkityksellistämistä, jotka vaihtelevat tilanteen mukaan yhdenkin ihmisen kohdalla. Saaristossa kiinnitytään elinpiiriin tuttuuden ja omaksi koetun toimintaympäristön kautta, toisaalta suhteessa sen ulkopuolella oleviin ja vieraaksi koettuihin alueisiin.

Aluekehitystyön piirissä saaristoa on pyritty kehittämään muun muassa erilaisten kulttuuri-, matkailu- ja koulutushankkeiden muodossa. Osassa kehityshankkeita niiden toteutus on rakentunut toimivalle yhteistyölle saariston arjen ja käytänteiden kanssa. Joissakin tapauksissa on toisaalta saattanut ilmetä suoranaisia ristiriitoja ja saariston asukkaiden näkökulmasta ulkoapäin tuotettujen mielikuvien ja symbolien käyttämistä saaristokulttuurin esittämisessä.

Tutkimuksessa kävi esimerkiksi ilmi, että kieliraja torjuvana elementtinä nousi esiin erityisesti aluekehitystyössä ja sen hankkeissa, ei niinkään ihmisten arjessa. VarsinaisSuomen saariston kaksikielisellä alueella on asunut vuosisatoja sekä suomenkielistä että ruotsinkielistä väestöä. Jokapäiväisessä elämässä kielet eivät useinkaan asetu kilpailevaan asemaan, mutta organisaatioiden toiminnassa kieliraja puolestaan näkyy selkeämmin. Kehityshankkeissa kielikysymys saattoi jossain tapauksissa korostua määriteltäessä sitä, mitä voidaan nostaa symbolisella tasolla esiin edustamaan laajemmin jotakin saaristokulttuuriksi määriteltyä. Toisaalta jotkut hankkeista myös yhdistivät ja edistivät toimivaa yhteistyötä suomen- ja ruotsinkielisen saariston kesken.

Siivonen nostaa esiin informaatioajan murroksen, jota juuri nyt elämme, ja jonka myötä esimerkiksi paikallisen erityisyyden esiin nostaminen on saanut uusia merkityksiä. Tutkimuskohteena oleva saaristo ja sen kehityshankkeet ovat osa näitä laajempia muutoksia ja niiden vaikutuksia. Käytännön tasolla saaristoon ja hankkeisiin vaikuttavat esimerkiksi erilaiset kansalliset ja kansainväliset organisaatiot ja instituutiot toimintaperiaatteineen ja tavoitteineen. Lisäksi Siivonen käy läpi myös muita saaristoon vaikuttaneita murroskausia, kuten 1800 -luvun lopulla alkaneen teollistumisen.

\section{SAARISTOKULTTUURIT JA KESTÄVÄ KEHITYS}

Jokapäiväinen elämä sisältää paljon tiedostettua ja tiedostamatonta, niin kutsuttua hiljaista tietoa, joka saattaa jäädä alueellisessa kehitystyössä huomiotta. Siivonen havaitsi myös, että organisaatioiden toiminnassa elää tiedostamattomia, juurtuneita käytänteitä ja toisaalta erilaisia kulttuuristen konstruktioiden tuottamista ja välittämistä koskevia tavoitteita. Nämä tavoitteet ja ihmisten arkinen todellisuus ja kokemukset eivät aina kohtaa. 


\section{KUKKA HAMMARSTRÖM}

Siivonen esittää, oman tutkimuksensa esimerkin avulla, miten aluekehitystyössä olisi mahdollista kohdata paremmin alueen arkinen todellisuus ja toisaalta kehittää eri osapuolten välistä vuorovaikutusta. Hänen mukaansa tulisi huomioida se, että kehitystyötä ohjaaville tahoille kulttuuri ei ole vain väline tai kohde vaan ne ovat myös itse osa kulttuuria. Hän korostaa, että kulttuurisesti kestävässä aluekehitystyössä olennaista on siihen liittyvien kaikkien tasojen, yksittäisten ihmisten sekä erilaisten paikallisten ja globaalien toimijoiden kulttuuristen prosessien huomioiminen sekä näkeminen suhteessa toisiinsa. Kehitystyössä tulisi myös huomioida laajemmin muutkin kuin sen kohteena olevat alueet ja paikallisuuteen kiinnittyvät seikat.

Tutkimuksessa niin saariston arjessa kuin aluekehitystyössä saaristoidentiteetit nousevat esiin dynaamisina, vuorovaikutuksellisina ja alati muuntuvina prosesseina. Kuten Siivonen itsekin toteaa, antroposemiosiksen prosessi antaa mahdollisuuden paitsi tarkastella kulttuurin toimintaa sen perustasolla myös laajempina vuorovaikutusverkostoina. Tämän kaltainen lähestymistapa tarjoaa laajan ja moninaisen näkökulman kulttuuriin käsitteenä ja samalla osana sitä todellisuutta, jossa elämme ja toimimme.

Siivosen teksti on huolellista ja selkeä. Paikka paikoin tämä huolellisuus näkyi kuitenkin liiallisena asioiden toistamisena. Kaiken kaikkiaan tutkimus on mielenkiintoinen ja sisällöltään pitkälle työstettyä ja perusteltua. Omalla kohdallani semioottinen lähestymistapa vaati auetakseen muutamia intensiivisiä lukukertoja. Siivosen tutkimuksen tuoma anti kulttuurin käsitteestä ja kulttuurisesti kestävästä kehityksestä käytävään keskusteluun on mielestäni virkistävä, uusi ja ajatuksia herättävä.

Filosofian maisteri Kukka Hammarström on folkloristiikan jatko-opiskelija Turun yliopistossa. 